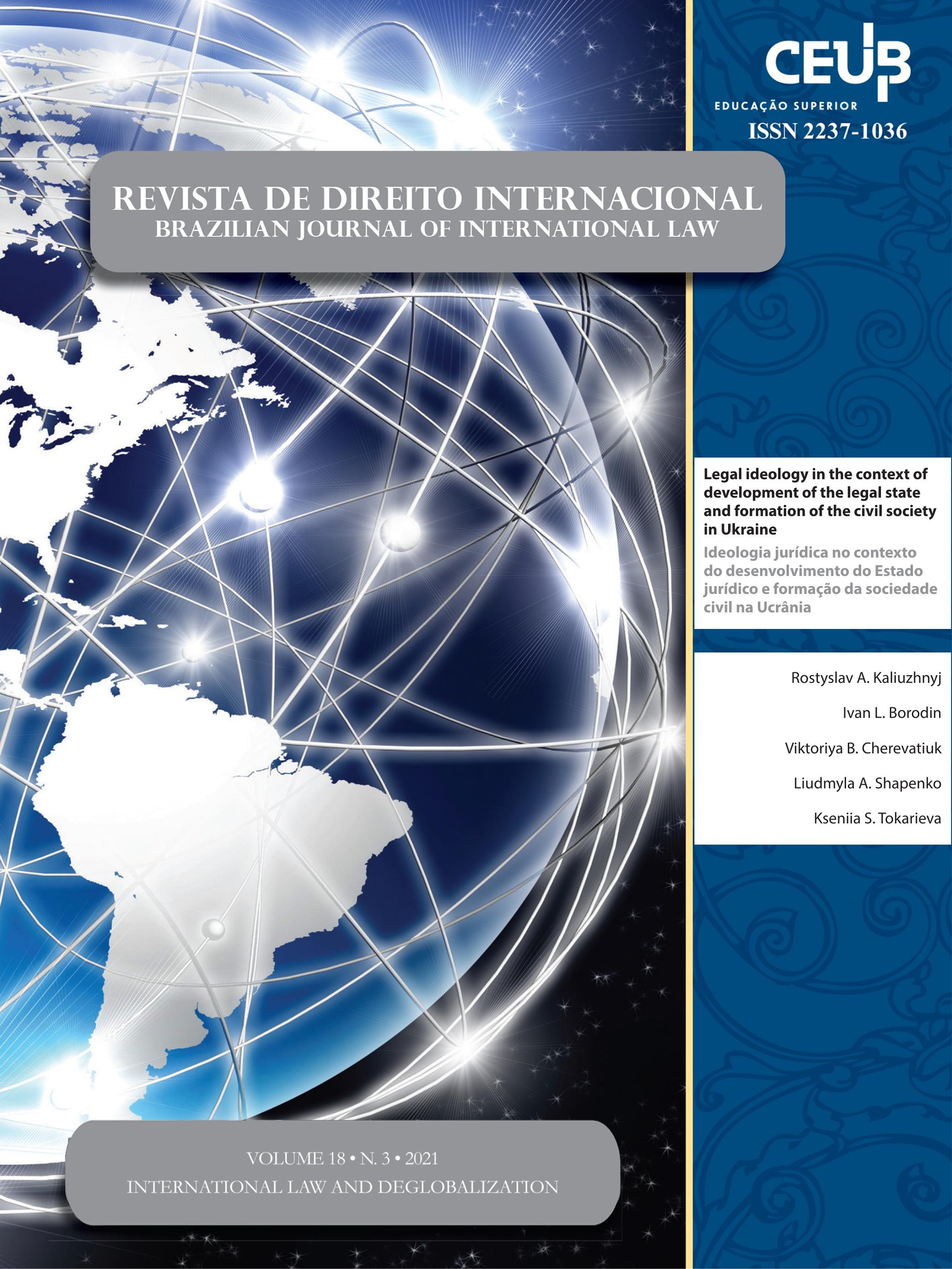




\section{Sumário}

Dossiê

EDITORIAL: INTERNATIONAL LAW AND DE-GLOBALIZATION 16 Ivette Esis, Jaime Tijmes e Juan Enrique Serrano

El régimen jurídico de la Inversión Extranjera Directa: ¿De la limitación a la desGLOBALIZACIÓN?

Ivette Esis Villarroel e Yoselyn Bermúdez Abreu

Desglobalização, Brexit e os novos acordos entre Reino Unido e União Europeia .34 Angela Limongi Alvarenga Alves e Daniel Freire e Almeida

FisCALIDAD Y DESGLOBALIZACIÓN EN UN MUNDO CRECIENTEMENTE UNILATERAL Julio César Muñiz Pérez

Covid, Covax e o Refluxo da Governança Global Salem Hikmat Nasser e Luiza Nogueira Papy

The International Monetary Fund and COVID-19: Old and New Challenges of a Post-World War II INTERNATIONAL INSTITUTION

Virdzhiniya Petrova Georgieva

Artigos Sobre outros temas

RULE OF LAW IN THE INTERNATIONAL ARENA: THE IMPORTANCE OF PRACTICES OF LEGALITY . 112 Angela Jank Calixto

THE WITHDRAWAL OF MEMBER-STATES FROM HUMAN RIGHTS COURTS: IS THE JUDICIALIZATION OF MEGA-POLITICS A NECESSARY CONDITION?. 132

Mikelli Marzzini Lucas Alves Ribeiro e Ernani Rodrigues de Carvalho Neto 
Princípio da precaução e mudança climática: uma análise do Acordo de Paris e das Conferências das Partes.

Jamille Bergamaschine Mata Diz e Carolina Mendonça de Siqueira

A INTERAÇÃo ENTRE OS ESPAÇOS CONSTITUCIONAIS NACIONAIS E INTERNACIONAIS E SEUS IMPACTOS NO SISTEMA DE FONTES DO DIREITO: AS LIÇÕES DA PROTEÇÃO COOPERATIVA DE DIREITOS HUMANOS E O CASO DA INTEGRAÇÃO EUROPEIA ...................................................... 173

Diego Fernandes Guimarães

WTO’s Engagement with National Law: Three Illustrations from India 193 Ravindra Pratap

GESTÃo MIGRATÓRIA E INTEGRAÇÃo REGIONAL: UMA ANÁLISE SOBRE A REGULAMENTAÇÃo NORmativa dos fluxos migratórios irregulares na União Europeia À luz do Novo Pacto Europeu sobre Migração e Asilo.................................................................. 212 João Mauricio Malta Cavalcante Filho e Eugênia Cristina Nilsen Ribeiro Barza

The African Regional Human and Peoples' Rights System: 40 years of progress and CHALLENGES. 232 Juan Bautista Cartes Rodríguez

The USMCA Sunset Clause 258 Jaime Tijmes-Ihl e Yvonne Georgina Tovar Silva

REFLEXÕES SOBRE A UNIVERSALIDADE DO DIREITO INTERNACIONAL DOS DIREITOS HUMANOS A RESPEITO DA PROTEÇÃO ÀS MULHERES 273 Érica Rios de Carvalho

A CRItical legal anAlysis OF GENDER EQUALITY IN INTERNATIONAL TRADE AgREEMENTS...287 Parul Shukla e Sheikh Sultan Aadil Huque

FEMinicídio, FEMicídio E Ódio NA AGENDA: o ASSASSinAto DAS MUlHERES NA AmÉriCA LATINA...... 309 Vinícius Ferreira Baptista

LEGAL IDEOLOGY IN THE CONTEXT OF DEVELOPMENT OF THE LEGAL STATE AND FORMATION OF THE CIVIL SOCIETY IN UKRAINE 
Direito INTERNACIONAL PÚBLICO NO ENTREgUERRAS (1919-39): A INSTITUCIONALIZAÇÃO DOS PROJETOS JURÍDICOS DE PAZ E MANEJO DOS POVOS NÃO SOBERANOS.

Hugo Luís Pena Ferreira

O Caso Gomes Lund (“Guerrilha Do Araguaia”) dez anos depois: Desafios para o cumPRIMENTO INTEGRAL PELO ESTADO BRASILEIRO

João Gabriel Archegas, Felipe Klein Gussoli e Vivian Cristina Lima López Valle

DiÁlogos museológicos: o Regime jurídico brasileiro e o Código de Ética do ConseLHo InTERnacional de Museus.

Paula Gonçalves do Carmo, Emerson Gabardo e Daniel Wunder Hachem 


\title{
Legal ideology in the context of development of the legal state and formation of the civil society in Ukraine*
}

\author{
Ideologia jurídica no contexto do \\ desenvolvimento do Estado jurídico e \\ formação da sociedade civil na Ucrânia
}

* Recebido em 24/05/2021

Aprovado em 27/09/2021

** Currently a member of the International Academy of Informatization, Academician of the Academy of Sciences of Higher Education of Ukraine, Chairman of the Specialized Academic Council for the Defense of Dissertations for the degree of Doctor of Law at the National Aviation University, Deputy Chairman of the National Academy of Internal Affairs, member of editorial scientific journals: "Europen Reforms Bulletin", "Interscience"; "Law and Society" and others.

Email: kaliuzhnyj8070@edu-knu.com

*** In 1993 he defended his PhD thesis and received the academic title of Associate Professor in 1997. In 2004 he defended his Doctoral thesis and received the academic title of Professor in 2007. Since February 2010 he has been working as a Head of Theory and History of State and Law Department of the Faculty of Law at National Aviation University. E-mail: borodin8070@sci-univ.com

**** $\mathrm{PhD}$ in History since 1997, Associate Professor at the Department of Theory and History of State and Law of the National Aviation University.

E-mail: cherevatiuk8070@acu-edu.cc

***** In June 2020 she defended a thesis for acquiring a scientific degree of $\mathrm{PhD}$ in Law.

E-mail: shapenko8070@edu-knu.com

****** Full Doctor in Legal Science, Associate Professor of the Department of Constitutional and Administrative Law at the National Aviation University in Kyiv, Ukraine.

E-mail: tokarieva8070@edu.cn.ua

\author{
Rostyslav A. Kaliuzhnyj** \\ Ivan L. Borodin ${ }^{* * *}$ \\ Viktoriya B. Cherevatiuk ${ }^{* * * *}$ \\ Liudmyla A. Shapenko***** \\ Kseniia S. Tokarieva ${ }^{* * * * * *}$
}

\begin{abstract}
The purpose of the article is to investigate the essence of legal ideology in its inseparable relationship with such categories as "law", "morality" and "justice", as well as to identify new content characteristics of this concept in terms of legal integration. The use of general scientific and special legal methods of scientific knowledge, in particular dialectical, axiological, systemstructural, generalization, allowed analyzing the general trends of the influence of legal ideology on the formation of a legal state and the formation of civil society. As a result of the scientific search the content and qualitative features of legal ideology were revealed, the main directions of research of the given category were outlined and the ways to overcome the proclamation of national legal ideology in Ukraine were proposed. Legal ideology is an element of the mechanism of self-organization of the legal system, and the legal system, in turn, determines the forms of self-organization and ways of functioning of the national legal system, which integrates all legal phenomena within a particular society of the state level; the formation of legal ideology must be based on a public dialogue of power and society by implementing generally accepted democratic procedures and modern democratic methods.
\end{abstract}

Keywords: Ideological conflict; morality; legal ideology; legal culture; legal consciousness; legal system; justice.

\section{Resumo}

O objetivo do artigo é investigar a essência da ideologia jurídica em sua relação indissociável com categorias como "direito", "moral" e "justiça”, bem como identificar novas características de conteúdo desse conceito em termos de integração jurídica. A utilização de métodos científicos gerais e jurídicos especiais de conhecimento científico, em particular dialético, axiológico, 
sistêmico-estrutural, generalização, permitiu analisar as tendências gerais da influência da ideologia jurídica na formação de um estado jurídico e na formação da sociedade civil. Como resultado da pesquisa científica foram revelados o conteúdo e as características qualitativas da ideologia jurídica, delineadas as principais direções de pesquisa da categoria em questão e propostos os caminhos para superar a proclamação da ideologia jurídica nacional na Ucrânia. A ideologia jurídica é um elemento do mecanismo de auto-organização do ordenamento jurídico, e o ordenamento jurídico, por sua vez, determina as formas de auto-organização e os modos de funcionamento do ordenamento jurídico nacional, que integra todos os fenômenos jurídicos dentro de um determinado sociedade do nível estadual; a formação da ideologia jurídica deve basear-se no diálogo público do poder e da sociedade, implementando procedimentos democráticos geralmente aceitos e métodos democráticos modernos.

Palavras-chave: Conflito ideológico; moralidade; ideologia jurídica; cultura jurídica; consciência jurídica; sistema legal; justiça.

\section{Introduction}

The issues of the development of the rule of law state in Ukraine and the formation of the national legal system require the study of legal ideology as sociocultural phenomenon, the transformation of which occurs at the same time as evolutionary changes in civil society. The notion of "ideology", which became central to the formation of the content of legal ideology, was introduced into the scientific vocabulary by the French philologist A. Destutt de Tracy, who in his multivolume work "Elements of ideology" outlined the doctrine of the general laws of origin of the idea of the content of life experience, its meaning for politics, law, morality ${ }^{1}$. The scientific grounding concerning the ideas was continued by K. Marx and F. Engels by considering ideology as a "false consciousness" used by a small number of people for their own purposes, often passing it as interests of the entire society in order to give legitimacy to a particular political elite ${ }^{2}$.

\footnotetext{
${ }^{1}$ SIROTA, N. M. Ideologies and ideological currents: classical heritage and modernity. St. Petersburg: IVESEP, 2009. 167 p.

2 MARX, K.; ENGELST, F. Selected works. Moscow: Politizdat, 1985. v. 2. 509 p.
}

Matvienko, the follower K. Mannheim generally considered ideology a system of ideas, which in a distorted form reflect objective reality ${ }^{3}{ }^{4}$. The philosophers such as R. Aron, K. Popper, S. Lipset and others contributed to the development of the doctrine of ideology, which, under the influence of positivism, put forward the theory of "de-ideologization", which, in their view, was influenced by science on social processes ${ }^{5}$. Instead, modern researchers E. Lees and E. Shepherd define legal ideology as a comprehensive form of political thinking that seeks to capture the meaning of essentially contested concepts, and its impact on the legal framework can be systematically analyzed by considering variations in how such concepts are interpreted in different legal contexts ${ }^{6}$.

The development of contemporary problems of legal ideology was carried out by such scientists as V. Astakhova $^{7}$, I. Yevkhutich ${ }^{8}$, A. Lutskyi ${ }^{9}$, S. Matvienkiv ${ }^{10}$, M. Nediukha ${ }^{11}$, N. Onishchenko ${ }^{12}$, I. Pys $\square$ mennyy $^{13}$, V.

${ }^{3}$ MANNHEIM, K. Ideologie und Utopie. Bonn: Friedrich Cohen, 1929, 250 p. Available at: https://books.google.com.ua/books?id= NxethJLLfGoC\&pg=PR53\&lpg=PR53\&dq=Mannheim, + K. + Ide ologie+und+Utopie.+Bonn,+1929. Accessed on: 3 May 2021.

${ }^{4}$ MATVIENKIV, S. M. Transformation of political consciousness in the conditions of formation of democracy in Ukraine: monograph. IvanoFrankivsk: NAIR, 2018. 252 p.

${ }^{5}$ KOLESNIKOVA, G. I. The social mechanism of manipulation of personality consciousness. Moscow: Direct Media, 2014. 272 p.

${ }^{6}$ LEES, E.; SHEPHERD, E. Morphological analysis of legal ideology: locating interpretive divergence. Journal of Property, Planning and Environmental Law, n. 10, v. 1, 2018. Available at: http:/ / centaur. reading.ac.uk/75250/. Accessed on: 3 May 2021.

7 ASTAKHOVA, V. I.; BOGIROV, V. S.; GORODYANENKO, V. H. et al. Sociological encyclopedia. Kyiv: Akademvydav, 2008. 561 p.

8 YEVKHUTICH, Morality and law in the system of social ideas and their place and role in the activities of the National Police of Ukraine: monograph. Lviv: Lviv Department of Internal Affairs, 2017. 212 p.

9 LUTSKYI, A. I. Modern philosophical-legal and theoretical-legal thought about legal ideology (experience of Ukraine and Post-Soviet countries). Bulletin of Zaporizhia National University: A Collection of Scientific Papers. Legal Sciences, n. 4, p. 24-30, 2013.

${ }^{10}$ MATVIENKIV, S. M. Transformation of political consciousness in the conditions of formation of democracy in Ukraine: monograph. IvanoFrankivsk: NAIR, 2018. 252 p.

${ }^{11}$ NEDIUKHA, M. P. Worldview-theoretical principles of legal ideology. Chamber, n. 21, v. 258, p. 27-30, 2009. NEDIUKHA, M. P. Legal ideology of Ukrainian society: monograph. Kyiv: MP Lesya, 2012. $400 \mathrm{p}$.

12 ONISHCHENKO, N. M.; PARKHOMENKO, N. M. Social dimension of the legal system: realities and prospects: monograph. Kyiv: Legal Thought, 2011. 176 p.

13 PYS $\square$ MENNYY, I. Public attractors as a basis for forming the synergetic potential of public administration. 2010. Available at: http://www.dridu. dp.ua/vidavnictvo/2010/2010_04(7)/10pivppu.pdf. Accessed on: 3 May 2021. 
Tolstenko ${ }^{14}$, L. Udovyka ${ }^{15}, \mathrm{H}$. Hart ${ }^{16}$, etc. The analysis of the majority of scientific works affirms that the consideration of the essence of the concept under study and its interrelation with other legal categories, mostly taking into account the laws and principles of dialectics. However, in view of the belonging legal ideology to the multi-elemental composition of the legal system, characterized by openness and interaction with the environment, it is necessary to study the synergistic regularities of the emergence and development of various socio-legal phenomena in the material world and the world of ideas, in particular such as: positive law, legal consciousness, ideology, morality, legal regulation, etc. ${ }^{17}$ That is, the main task is to find out the role and place of the legal ideology in the process of forming the rule of law state, its influence on the formation of civil society within the sociocultural approach and by resorting to the laws of synergetic as a scientific method of describing the processes of self-organization in complex systems, which are now one of the most progressive and in-demand legal knowledge.

The object of this study is the social relations in the process of formation, development, legal consolidation and realization of the basic principles of legal ideology. And the subject of the study is legal ideology and its role in ensuring the development of the modern Ukrainian state and civil society. Thus, the purpose of the article is to determine the essential "filling" and content of legal ideology in view of the systematic relations with other legal phenomena and the ability to self-organize inside the system, as well as to develop conceptually new approaches to improve the mechanisms of formation of national legal ideology under the conditions of European integration and globalization transformations of the national legal system of Ukraine.

\footnotetext{
14 TOLSTENKO, V. L. Legal ideology in the structure of legal consciousness: theoretical and methodological bases of analysis. State and Law: Collection of Scientific Works. Legal and Political Sciences, $\mathrm{n}$. 41, p. 10-18, 2008.

15 UDOVYKA, L. G. Transformation of the legal system in the context of globalization: anthropological dimension: monograph. Kharkiv: Pravo, 2011. 552 p. UDOVYKA, L. G. Legal system of Ukraine: globalization transformations. Zaporozhye: KSK, 2014. 320 p.

${ }^{16}$ HART, H. L. A. Are there any natural rights? Philosophical Review, n. 64, v. 2, p. 175-191, 1955. Available at: https://www.jstor.org/ stable/pdf/2182586.pdf?seq=1. Accessed on: 3 May 2021.

17 MARKOVYCH, K. Legal ideology as a basis of forming civil society. Law, n. 885(12), v. 1, p. 418-423, 2016.
}

\section{Legal ideology in the context of globalization}

The formation of a democratic social and legal state is organically linked with the formation of a civil society in which the embodiment and all-round development of each individual is ensured. A significant role in the implementation of these processes belongs to the legal system, its components - the system of law, new legal relations as a form of creative legal activity, which is sanctified by a highly developed legal consciousness and legal culture ${ }^{18}$. One of the structural elements of the national legal system in the context of globalization is the legal ideology, the prerequisites for the existence of which is the need to regulate public relations by influencing the legal consciousness of citizens and other elements of the legal system through legal ideology; the need to prevent legal voluntarism, the use of negative legal phenomena (legal nihilism, mass dehumanization and demoralization), the presence of legal norms and value orientations that require handling by means of legal ideology. The point at issue is the impossibility of sustainable reproduction of the national legal system and the formation of civil society without a doctrinally justified and consistently enshrined in the system of legal norms and institutions of legal ideology. After all, legal regulation, as a purposeful effective impact of law on specific social relations in order to streamline and improve them with the help of special legal means, is not able to be effective outside the system of those ideas and values that set the goals of such impact, express the social and special legal value of law as a unique system of social regulation.

\subsection{Synergetic patterns of interaction of legal ideology with other elements of the legal system}

As noted above, the openness of the legal system and its interaction with the environment determine the need to apply synergy laws in order to determine the synergistic patterns of interaction of various social and legal phenomena within this system. Since the legal system is generated by society and a functional part of its existence, it is being developed due to consideration of

\footnotetext{
18 ONISHCHENKO, N. M.; PARKHOMENKO, N. M. Social dimension of the legal system: realities and prospects: monograph. Kyiv: Legal Thought, 2011. 176 p.
} 
the need to regulate certain social relations by the rules of law. That is, society is the environment for the legal system, which, in turn, is a subsystem of a higher level - the social system. Permanent processes of energy and information exchange take place between society and the legal system. Moreover, information about social needs serves as a starting point for the formation of structures in the legal system (legal systems, legal institutions, legal relations, etc.). The legal system also actively influences the state of society, changing its energy characteristics and promoting (or hindering) its movement to the attractor state, which is determined by its possibilities of self-organization and the quality of regulatedness of relations in society.

Such potential opportunities of society in its unity and integrity determine the path of social development, which can be both evolutional and involutional. This is due to the interdependence of self-organization processes from other social processes that have the opposite direction and can at certain periods of the system's development both dominate and give way to self-organization processes ${ }^{19}$. Therefore, it should be taken into account that the social system contains other subsystems - economic, political, and ideological, which have a close interrelation and mutual influence among themselves and thus with the legal system. This once again emphasizes that the search for optimal ways to develop the legal system should be carried out on the basis of the study of synergistic patterns of the legal elements of the system in combination with elements of other subsystems of society, including the ideological one. It is synergetic that can offer new searches for centuries-old philosophical questions about the relationship between the material and the ideal in legal life, the causes and forms of existence of legal matter, the mechanisms of relations between people, awareness of the boundaries of permitted behavior in society, the boundaries of legal recognition, the direction of society development, etc.

Explanation of legal ideology and other interrelated legal phenomena from scientific point of synergetic with methodology point of view is comprehensive, deep, not evolutionary, but revolutionary in nature, which allows to obtain non-obvious and progressive scientific results

19 PYS $\square$ MENNYY I. Public attractors as a basis for forming the synergetic potential of public administration. 2010. Available at: http://www.dridu. dp.ua/vidavnictvo/2010/2010_04(7)/10pivppu.pdf. Accessed on: 3 May 2021. of description of the most common features of the dynamics of the legal system and its structural elements, not by exploring their essence, but by the characteristics of the systemic connections between them.

Taking into account the above, it may be concluded that the legal ideology comes from a general ideology that represents an objective, goals for society and each person, and citizen. Most scientists consider the concept of ideology as a system of views, ideas, beliefs, values and attitudes that express the interests of various social groups, classes, and societies, in which people's attitudes to reality and to each other, social problems and conflicts are realized and evaluated, as well as goals (programs) of social activities aimed at consolidating or changing of existing social relations ${ }^{20}$. Ideology is a kind of verbal formula, which includes assessments and actions for citizens and the state, which is widely spread in society, determines the place and role of a person in society, and establishes optimal, more rational options for her relationships with other members of society.

It is worth noting that the ideology is always based on the needs both of each individual and society as a whole. Needs determine the direction of the organism, an individual to create and implement the conditions of existence and development. Moreover, the satisfaction of most human needs (physical, social and spiritual) is possible only through their formal-legal recognition and legal mediation of the satisfaction mechanism itself ${ }^{21}$. And here the central place will belong to moral and values, which, having biological roots, have repeatedly been processed in the process of adaptation in society, have been fixed in verbal formulas - beliefs that are an integral element of social consciousness. Consideration of the latter is of particular interest, since it has a direct impact on the formation of national ideology in the state, including legal ideology.

\subsection{Public and legal consciousness as factors of legal ideology}

Social consciousness is traditionally divided into such forms as: political, legal, moral, aesthetic, religious

${ }^{20}$ GERASINA, L. M.; POGRIBNA, V. L.; POLISHCHUK, I. O. Political science encyclopedic dictionary. Kharkiv: Law, 2015. 816 p.

${ }^{21}$ KALIUZHNYJ, R. A.; SHAPENKO L. A. The conceptual content of subjective law in terms of legal integration. Scientific works of the National Aviation University. Series: Legal Bulletin "Air and Space Law", n. 4, v. 53, p. 54-61, 2019. 
and philosophical ${ }^{22}$. This distribution can be considered horizontal because each of the forms is located in the same plane of social consciousness and is interconnected and interdependent with each other. Along with this, it is necessary to distinguish between two levels of "vertical" social consciousness: social psychology, which is a mass (group and society as a whole) consciousness, which is formed directly in the process of social practice, and ideology, which should be understood as a system of ideas or systematized social consciousness produced by specialists-ideologists. Systematization of ideology characterizes the ideological level of public consciousness, which, in turn, depends on the awareness of social reality in both theoretical and practical aspects. Consideration of ideology in this way makes it possible to thoroughly understand the nature of this phenomenon. After all, theoretical consciousness is the knowledge of the essence, laws and order of certain spheres of reality, and practically systematized consciousness is a system of ideas that evaluate the usefulness of certain things and objects, as well as methods of using them or preventing negative effects from them.

Legal consciousness as one of the key derivatives of the public consciousness occupies a central place in the legal life of the society because clearance and enforcement of the law occurs through the human perception and understanding of legal phenomena, evaluating the specific circumstances as legally relevant, and regulating their own and others' behavior through a system of motives, value orientations, legal goals. At the same time, taking as a basis the division of consciousness into individual and social, it is worth noting that individual consciousness does not always determine social consciousness. Since the social nature of a person, for example, the fear of being alone makes her in the vast majority of cases to join the majority opinion, in particular to the public legal consciousness, which is based on the prevailing at a certain time legal ideology ${ }^{23}$. That is, legal consciousness should be perceived as an understanding of law, a set of ideas, feelings, and emotions, volitional and intellectual processes that express the attitude of humanity to both the existing and the desired law. All

\footnotetext{
22 MATVIENKIV, S. M. Transformation of political consciousness in the conditions of formation of democracy in Ukraine: monograph. IvanoFrankivsk: NAIR, 2018. 252 p.

23 MATVIEIEVA, L.; BALTAJI, P.; KONOPELSKY, V. Role of modern legal elite in formation of legal culture of Ukrainian society. Asia Life Sciences, n. 2, p. 385-403, 2019.
}

these elements are linked together and form a complete unity, a system permeated with a common idea.

However, in this system, the main components are ideas and norms, which manifest the specificity of legal consciousness. The essence of this specificity is that the legal consciousness objectively requires the establishment of mandatory rules of conduct, legal rights and obligations for all participants in public relations. Legal consciousness in this aspect can be considered as a form of public consciousness, which is based on the desire of the public authorities to forcibly subordinate all personal and group interests to the goals of adoption of their own interests as national ones. Without this, there is neither legal consciousness nor legal forms of human behavior. This means that the study of the relationship between law and legal consciousness is important for revealing the structure of legal consciousness and the purpose of its functions. It contributes to a deeper understanding of the question of the place and role of the reportable element in the implementation of legal norms, finding out ways and means of improving legal regulation, and, in turn, generating new ideas for the development of society, which in the future may become an integral part of the legal ideology.

The above analysis of the interdependence of ideology and social consciousness, including the legal one, allows characterizing ideology as an object of philosophical analysis, which makes it possible to reveal the heuristic (cognitive) possibilities and social spheres of ideology. Due to having objective social and political roots in the conditions of life and consciousness of people, ideology, including legal, as a specific form of consciousness is formed as a result of the differentiation of society, the separation of the Church from the State, especially with the emergence of nations and the formation of sovereign states. Ideology arises from the need for some part of society to receive and provide support from the population for its policy, a certain political course, and program. Ideology can perform this role by expressing the interests of groups, classes, nations, and states, as well as responding to their worldview and communication needs. That is why ideology is also a powerful tool for organizing people, managing them and their behavior. 


\subsection{Pluralism of ideologies in conditions of information society formation}

Understanding the main aspects of the formation of the $\mathrm{c}$ and civil society also requires observing the movement of a new ideology of post-industrialism, in which a qualitatively new type of society has emerged - the information-oriented society, which involves the activities of people based on the use of services provided by information and communication technologies ${ }^{24}$. Its appearance had certain theoretical roots, as the idea of informational society was formed in discussions of the futurists, techno-optimists, eco pessimists and the globalists, however, this concept is constantly being improved, considering the characteristics of social development which are based on the increasing importance of information ${ }^{25}$. A striking example of the interaction between the state and society in the development of the information society is the improvement of feedback forms in the European Union and the shift of emphasis from outdated ideas to the idea of achieving social unity of nations. For example, in France, in order to build an e-state, the government website Débat Public was launched, where citizens express their opinions on important infrastructure solutions ${ }^{26}$. The latest technologies make it possible to modernize existing forms of direct democracy and give the state a new role - a partner one.

The history of human systems can be viewed in two dimensions: technical and ideological. And when now the issue is about the formation of information-oriented society and information-oriented society, it is simply impossible without the existence of certain ideas for building, developing and streamlining of relations in such conditions. The essence of ideology as a generic concept on its derivatives, in particular political and legal ideology, in the modern sense can be interpreted as a set of basic ideas and provisions that embody the values, interests, principles of a particular society, group

\footnotetext{
${ }^{24}$ EUROPEAN COMMISSION. White Paper on growth, competitiveness and employment: the challenge and ways forward into 21 st century. Available at: https://op.europa.eu/en/publication-detail/-/ publication/4e6ecfb6-471e-4108-9c7d-90cb1c3096af/language-en. Accessed on: 3 May 2021.

25 SOPILKO, I. M. Methodological bases of scientific comprehension of the concept of information society. Legal Bulletin. Air and Space Law, n. 1, p. 80-84, 2014.

26 DZYUNDZIUK, B. V. Foreign experience of interaction of authorities with citizens in the conditions of development of information society. Bulletin of the National University of Civil Defense of Ukraine. Series: Public Administration, n. 2, p. 94-101, 2016.
}

of people, scientific direction, and so on $^{27}$. Therefore, ideology is a necessary and important element of modern social life. It is represented by a wide range of different value systems and programs for their implementation.

Western society, especially the states of the Anglo-Saxon legal system, has long established common understanding of civil society as a political articulation of interests and coordination of individual elements of society. Whereas in the post-Soviet states, civil society did not exist in this sense, and over time it acquired another dimension of understanding - as a part of a legal ideology that delegitimizes socialist ideology ${ }^{28}$. In Ukraine, after long domination of a single ideology (communist) and a kind of de-ideologization of society, ideological pluralism is gradually being established. Article 15 of the Constitution of Ukraine establishes the constitutional principle: no ideology can be recognized as mandatory, which makes it clear that there is equality of ideologies in Ukrainian society. But the absence of a single or mandatory ideology does not mean that state authorities carry out their activities independently of any ideological principles, or are engaged in an ideological struggle in society. The existence of diversity, pluralism of ideologies in a social, law-governed state is an indicator of its democracy, openness to different ideological views, theories, and respect for the ideological aspirations of individual social groups. At the same time, legislation cannot be based on different types of legal ideologies in favour of certain social forces of society and the needs of a specific life situation, which is usually limited by temporary and spatial requirements. In such circumstances, neither the logical nor the technical and legal content of law, even if it is improved, is able to stabilize the national legal system and legitimize the main part of the legal system in the public legal consciousness - since these functions can only be performed by a well-formed legal ideology. In a state where there is a unified national legal system, it is also essential to have a unified, official, common, dominant legal ideology.

The nature of legal ideology is functional, its essence lies not so much in the content originality of certain legal ideas, but in the uniqueness of the functions perpean Societies, n. 12, v. 3, p. 293-315, 2010. 
formed in relation to all levels of legal consciousness, the system of positive law, legal practices, education, and the entire legal system as a whole ${ }^{29}$. The very meaning of a particular legal ideology exists only as long as it is able to exercise ideological influence on various levels of legal consciousness. In other words, for the validity of legal ideology, it is not enough only official establishment and consolidation by the legislator of certain ideas in the formal sources of law. It is necessary that legal ideas actually exercise their influence on the consciousness and behavior of subjects of the legal system by establishing and updating a set of values and goals, forming attitudes and representations in the public and group legal consciousness, and corresponding orientation of legal behavior. Without performing their basic functions, legal ideas cease to be part of the legal ideology, presenting only their declarative character. The criticality of the situation that has developed as a result of the pluralism of ideologies formed in the political sphere of the Ukrainian state is being overcome by the influence of a declared but fixed ideology in the Basic Law of Ukraine (independence, democracy, the presence of various forms of property, panhuman morality, social security, etc.), which is based on the concept of anthropocentrism in the modern legal doctrine.

Ukraine as an independent sovereign state has the necessary and sufficient conditions for the formation of a national legal ideology that would meet certain characteristics of the identity of Ukrainian society in the era of informatization, the law-governed state and civil society, formed under the influence of globalization processes, self-sufficient personality and mentality of the people. However, the main condition for the formation of legal ideology is its monistic character in the content and functional subordination to the rule of law, focus on the goal and objectives of the process of social changes, and the means of their legal support etc. ${ }^{30}$ The unattainability of these requirements so far proves the lack of formation of the domestic legal ideology, which regionalizes the domestic legal space, generates a weakness of legal system, divides the unified legal cul-

\footnotetext{
29 ALIMBEKOVA, M. A.; IBRAYEVA, A. S.; ICHSHANOVA, G. T.; USEINOVA, K. R.; IBRAYEV, N. S. Legal culture of public servants: The comparative legal analysis of the formation practices of various countries. Journal of Advanced Research in Law and Economics, n. 7, v. 10, p. 1956-1967, 2019.

${ }^{30}$ UDOVYKA, L. G. Transformation of the legal system in the context of globalization: anthropological dimension: monograph. Kharkiv: Pravo, 2011. 552 p.
}

ture into "Eastern" and "Western", leads to the loss of clear political and spiritual guidelines and, as a result, to permanent political instability and confrontation ${ }^{31}$. As a result, the evolution process from libertarianism to Ukrainian centrism of the ruling parties and the attempt to introduce this concept as the ruling ideology among the entire Ukrainian society is obvious for now.

\subsection{Legal ideology, law and morality}

As it is known, any state cannot fail to perform its ideological function, the tasks of which are moral, legal and value consolidation of society, mobilization of its potential to achieve certain, first of all, constitutionally defined goals, removal of social tension, and legitimization of state power. This indicates the basic elemental composition of the ideology: morality, values, distribution of property, information and power, which in their unity ensure the implementation of the ideological function of the state, aimed at forming the political and legal consciousness of citizens, affirming the values of the law-governed state and civil society, the unity of the people.

Centuries of experience, the accumulated system of philosophical knowledge, which is permeated with a variety of ideas and principles, do not give a clear answer to the question of what constitutes law. All periods of civilizational development are permeated with the idea of the value of an eternal character (morality, justice, equality, freedom). Therefore, it should be noted that for many centuries, the moral dimensions of human existence prevailed, which, in turn, influenced the formation of higher-order values, and later legal attitudes. The search for a moral law and higher-order values that would determine the entire process of human life does not lose its relevance in our time ${ }^{32}$. Therefore, the study of the genesis of law is advisable to start with the analysis of mechanisms for the formation of norms of public morality and public opinion on certain behavioral acts and states.

Researchers, as a rule, consider morality, as well as the mechanism of interaction between law and morality, through the prism of public consciousness, which

\footnotetext{
31 NEDIUKHA, M. P. Worldview-theoretical principles of legal ideology. Chamber, n. 21, v. 258, p. 27-30, 2009.

32 SHEVCHENKO A. E.; KHOLODNIUK S. Z. Socio-legal value of man in modern law: monograph. Vinnytsia: LLC “TVORY”, 2019. 268 p.
} 
allows not only to provide an objective definition of morality and its derived categories, but also to justify the role and importance of moral principles in building effective ways to improve the mechanism of legal regulation and the establishment of standards of public behavior and activities in various areas of public life in general.

Morality is not only an independent form of social consciousness, which has a direct impact on the legal consciousness, but also the main factor in the formation of the theory of natural law and the expansion of legal understanding by including both the norms of official law and the legal norms of reality in it. Usually, morality is defined as a set of norms of individual behavior in society or as a form of consciousness that regulates a person's relationship to society and other people. Moral consciousness, like every form of social consciousness, is characterized by a specific social function that is aimed at regulating behavior in society ${ }^{33}$. At the same time, it should be noted that morality is not only one of the main types of social regulation, a kind of organization of the real process of human activity, but also a stimulus for the development of individuality, changes in social relations. After all, the objective needs of society, being fixed in morality, take the form of assessments, general rules and practical prescriptions.

As it is noted by the Czech researcher I. Popelova, moral relations include moral actions, behavior, skills of individuals or groups, public institutions, activities aimed at implementing the moral relations of this society (the objective side of moral relations); moral consciousness, moral feelings, moral beliefs, aspiration (the subjective psychological side of moral relations); moral goals, moral ideas, codes of moral values and norms (the ideological, theoretical side of social relations) ${ }^{34}$. The main thing in this classification is the division of moral relations into objective and subjective sides, which allows considering moral relations as an independent type of social relations.

Law and morality are the value-based forms of human existence that are always at the heart of the life of society, different peoples and states. Over the entire his-

\footnotetext{
33 YEVKHUTICH, I. M. Morality and law in the system of social ideas and their place and role in the activities of the National Police of Ukraine: monograph. Lviv: Lviv Department of Internal Affairs, 2017. 212 p. 34 POPELOVA, I. Ethics. On historical and modern issues of moral theory. Moscow: Progress, 1965. $672 \mathrm{p}$.
}

tory of civilization, they have alternately become an instrument for regulating social relations, thereby influencing the formation of state policy, the formation of the individual, and his or her perception of the world. That is why the question of the correlation between law and morality has not lost its relevance among scientists of different times. This issue has received special attention in the context of the formation of a democratic society and law-governed state, in which the main task is to ensure the rights and freedoms of human and citizen, which, in turn, leads to changes in ideological attitudes, in particular regarding the interaction of the citizen and society, as well as society and the state as a whole. All this is a prerequisite that makes it necessary to study the mutual influence of law and morality to determine the content of legal ideology and its role in the process of improving the mechanism of social regulation, as well as to develop new approaches to the implementation of various types of law-making activities, which in modern conditions is undergoing significant transformations and is increasingly based on one of the most important ideas of humanity - justice.

\subsection{Justice as a moral and legal component of legal ideology}

Philosophical and legal thought has long put forward the principle of justice as a key principle underlying the determination of the degree of certain social benefits in the sphere of legal relations. The moral ideal is the basic one in the system of law since it determines its true spiritual essence and law-blessed life. This ideal is the basis for the recognition of the principle of justice as the main measuring criterion of normative choice in solving legal issues. The idea of justice as well as the very sense of justice is immanently inherent in the legal consciousness of civilized humanity. The beginning of justice motivates the development of behavior, activates and optimizes it, and creates a sense of legal responsibility in people.

Justice is defined by the category of moral consciousness, which characterizes the measure of influence and security of the rights and benefits of the individual or social community, the measure of requirements for the individual or the entire society. It can also act as a criterion for moral evaluation, as a feeling, norm, motive of behavior, and moral ideal. The values of the idea of justice are of important motivational value. After all, 
most of the citizen's actions can be dictated not by personal needs and interests, but by the interests of other people and society as a whole, based on ideas about useful, correct, and fair. Justice is a morally justified criterion for measuring the actions of subjects, according to which everyone is rewarded for their actions in the form of certain consequences. That is, justice involves comparing behavior and its evaluation, for example, the relationship between work and reward, merit and recognition, rights and responsibilities. The comparative attribute of justice determines its relationship with law and, above all, with the institution of legal responsibility. From this point of view, justice is expressed in the equality of citizens before the law, in accordance with the type of responsibility and public danger of an offence, in the correct application of the penalties by the relevant authorities.

Justice serves as a kind of standard (model) for evaluating alternatives (options) of behavior in the case of making a decision about goals and means to achieve them. Developed sense of justice is one of the means of internal moral control, which is closely related to the legal consciousness of the individual. Thus, justice, being at its core a category of morality, has an important regulatory value for legal behavior, and also serves as an integral element of legal culture.

Taking into account the theory of natural law, which now is becoming more and more relevant, as it follows from the inherent human desire for a justified social order, it can be unquestionably stated that justice is embodied in law since the law is a manifestation of justice. In people's views, justice was often associated with the law (for example, in the Romans, jus - law, justice - justice). In the very concept of justice, law embodies the connection with morality. Therefore, we should agree that law in all its manifestations, such as the regulatory system, public relations or justice, should be permeated with morality, which will serve as one of the most important conditions for its effectiveness. Of course, it is impossible to compare moral and legal rights so easily, but this close connection between them is precisely the feature that distinguishes moral law from other fundamental moral concepts. This means that the law belongs to the area of morality, which aims to clarify the possibilities of one person's freedom to restrict the freedom of others, and, accordingly, to determine those actions that can become the subject of binding legal rules (norms) ${ }^{35}$.

Given the fact that moral regulation, the object of which is human behavior in society, is carried out through moral choice, that is, by giving preference to public interests over personal ones, it is important to understand the motives for such a choice. The complexity of this choice is largely due to the internal contradiction of morality itself, which assumes the harmony of each of its sides - humanism and collectivism. After all, the social function of morality is to ensure the integrity of society, and the collectivism remains leading side of morality. And if there is a need to make a stark choice between different sides of morality, humanism usually remains on the sidelines. Although, this situation should not be identified with anti-humanism, since individual violation of humanism is a condition for its preservation in society as a necessary condition for the existence of humanity. Speaking about the perception of morality through each of its sides, it is worth noting that the degree of awareness of the need for humanistic and collectivist forms of social life depends on the level of development of society as a whole, and on the level of spiritual maturity of the individual. Subject to this, morality can change with the development of the material and spiritual conditions of human existence.

The above proves that morality, law, and justice are closely related and quite close concepts to each other. The law loses its moral value if it does not provide justice. There is no doubt that the law in all its manifestations must contain, express and implement justice and morality - the most important social and spiritual values. It is the law that is able to implement the principle of truth, the idea of justice, not only in general terms but also in each legal act and prescription. Justice is quite specific and, as noted in the philosophical and ethical literature, it is an evaluative moral category that expresses the attitude of an individual, social group, society to certain phenomena or actions, which, in turn, forms the basis for the formation of legal ideology.

The study of synergetic patterns of legal ideology and other major interdependent legal phenomena of the legal system leads to the conclusion that the clarification of the possibilities of legal ideology as a political

35 HART, H. L. A. Are there any natural rights? Philosophical Review, n. 64, v. 2, p. 175-191, 1955. Available at: https://www.jstor.org/ stable/pdf/2182586.pdf?seq=1. Accessed on: 3 May 2021. 
and legal phenomenon is also associated with the understanding of its essence in the multi-paradigm dimension, as well as the ability to socio-legal positioning and construction of social space. In multi-paradigm dimension, the legal ideology can be defined as a system of legal ideas, views, concepts and theories, that reflect the interests of social groups of society; a holistic socio-legal formation, which aims to ensure the functioning of the basic functions of society, formation of civil society and the law-governed state; social and cultural phenomenon actualized by social group or individual that allows to find the relevant definitions of its nature, functions and purpose in society ${ }^{36}$.

In modern legal literature, it is noted that legal ideology as a component of the general ideology not only produces a certain understanding of social reality and its development prospects, but also contributes to the establishment of a certain social order, offers values, ideals, and norms of law that determine the legal foundations of Ukraine as a state and its development prospects ${ }^{37}$. The ideas that should be contained in the legal ideology are value orientations that have an active influence on lawful behavior and the development of public relations. These ideas have a significant impact on the law-making process and serve as evaluation guidelines in relation to legal norms. In particular, special attention is currently required to the problem of interaction of law and morality in the activities of judges, since they in the conditions of expanding their competence in the field of law-making are more perfect "exponents" of law than the legislator himself. This is evidenced by the emergence of "soft law", which provides for the ability of a judge to specifically solve legal problems based on their own beliefs and quickly responding to changes in not only legal but also social reality ${ }^{38}$.

\footnotetext{
36 NEDIUKHA, M. P. Legal ideology of Ukrainian society: monograph. Kyiv: MP Lesya, 2012. 400 p.

37 UDOVYKA, L. G. Transformation of the legal system in the context of globalization: anthropological dimension: monograph. Kharkiv: Pravo, 2011. 552 p.

38 THÜRER, D. Soft law. Oxford Public International Law. 2009. Available at: https://opil.ouplaw.com/view/10.1093/ law:epil/9780199231690/law-9780199231690-e1469?prd=EPIL. Accessed on: 3 May 2021.
}

\section{Formation of national legal ideology in Ukraine}

The formation of national legal ideology has become an urgent issue of the Ukrainian legal life, since it contains, firstly, ideological counterbalances, restrictions, prohibitions concerning unlawful phenomena and actions, and secondly, ideological incentives, motives that contribute to the identification and reinforcement of legitimate principles in society. The social purpose of legal ideology is that it is a continuation of the existence of law in socio-legal practice, in the system of social and legal relations that are objectively formed under the influence of law. The functionality of legal ideology is a manifestation of legal influence on public life. This influence is characterized by certain ways, forms, methods, implementation of the principles of law in the activities of official institutions, as well as normative, moral, psychological and other factors. The content of the legal ideology is wide and diverse, it has many components: the strategy of legislation, the principles of legal regulation, constitutional construction, administrative and judicial reforms, the protection of human rights, the improvement of electoral law, the foundations of democracy, statehood, strengthening the rule of law, law and order, etc. In our opinion, the idea of natural law should be the main idea of legal ideology.

\subsection{Natural legal foundations of national legal ideology}

The natural-law component of the legal system reflects the origins of law as an integral part of human being, in which the measure of freedom is put, conditioned by nature and human communication, which is necessary for the normal existence of a human, and hence is the set of natural rights and duties: the right to life, property, personal independence, happiness, the obligation not to seek life, freedom of another person. The idea of natural law acts not only as a reliable means of limiting omnipotence, but also as a tool for social protection of a human in the state. It is extremely important to keep in mind the laws of development of the legal past of the country, because any history is not a chaotic accumulation, but a logically constructed system. This also refers to legal history, which is a "field" of legal analysis for scholars. Any ideology should have a historical aspect, if it pretends to scientific validity. 
The public consciousness first of all should analyze and understand the legal lessons of one's own tradition of law. This will allow the Ukrainian legal idea to remain in the spiritual coordinates of the national legal awareness, that is, to develop the national legal consciousness. It is difficult to understand the legal spirit of the people without this, their legal traditions, impulses, experiences, stereotypes of behavior. In other words, there is the matter of how preserve social and legal information and historical legal memory in the Ukrainian legal consciousness.

Legal ideology should be based on legal experience, the achievement of a universal legal civilization. But here it is better to choose the appropriate legal optimum, herewith observing the measures, rather than mechanically adjust the Western legal institutions and values to the national legal environment. That is, to perceive creatively, understand the content and significance of the global legal tradition, and only then to borrow from this experience what is necessary and will helps to change the Ukrainian social and legal reality for the better. An important point of legal ideology is spiritual, moral, ethical principles. The presence of spirituality in legal ideology is a prerequisite for its viability and progressiveness. Spirituality does not allow legal negativity to become a dominant phenomenon in the legal system of society. The moral aspect in legal ideology should become the unifying beginning of legal constant and changing components (ideas, theories, hypotheses, schemes, programs, etc.). The success or loss of any ideology, including the legal one, to a great extent depends on its connection with the cultural foundations of the life of the people and society.

Therefore, it is directly aimed at the society, lives (turns over) in a certain cultural environment, space that has personal, own traditions, customs, habits, stereotypes, images of perception, evaluation, sense of social reality. It is important to combine legal and ideological principles and provisions with the cultural spirit of society without violating the sociocultural matrix. Ideology cannot be separated from the general cultural context because it is its part. Law, the legal system, including legal ideology, cannot stay away from the influence of religion, its culture and values ${ }^{39}$. Moreover,

39 VAPNIARCHUK, V. V.; PUCHKOVSKA, I. I.; TAVOLZHANSKYI, O. V.; TASHIAN, R. I. Protection of ownership right in the court: the essence and particularities. Asia Life Science, n. 2, v. 21, p. 1-19, 2019. the peculiarity of national reality is connected with the religious diversity and the number of religious beliefs. As an embodiment of law, legal ideology is a systematic view of legal reality, which is based on a set of related beliefs, guidelines, legal views and norms that form social and individual legal awareness, contribute to the affirmation of a certain legal order, legal relations, influencing on all spheres of social life - economics, politics, culture, morals, etc.

\subsection{Legal ideology in Ukrainian society is under the influence of the global legal environment}

Legal ideology is a social phenomenon, a component of the ideological function of the state, which manifests itself, primarily, at the theoretical level, since it is a form of systematic theoretical knowledge. And in this sense, the veracious is the statement that legal ideology is a systematic set of legal ideas, principles, values, ideals, theories, concepts that are formed in society (independently or through purposeful state activity, reflecting the existing state of legal relations, defines the basis of social perception of law and order, sets the basic goals of the development of the legal system and the legislative system in the state ${ }^{40}$. The value of legal ideology in the national legal system points to the fact that, beyond the meaningful transformations of the modern national legal ideology, taking into account its global challenges and threats, is significantly complicated the formation of strategic priorities of legal development, their practical implementation, first of all, building a sovereign legal democratic state, civil society, ensuring and protecting constitutionally proclaimed human and citizen rights through the processes of European integration and globalization ${ }^{41}$. Globalization as an objective process leads to the formation of a global legal environment, the expansion and consolidation of international and European legal principles and standards. Under these conditions, there is a need to create a domestic social and legal environment that could be combined with European and global legal environment on the ba-

40 TOLSTENKO, V. L. Legal ideology in the structure of legal consciousness: theoretical and methodological bases of analysis. State and Law: Collection of Scientific Works. Legal and Political Sciences, n. 41, p. 10-18, 2008.

${ }^{41}$ UDOVYKA, L. G. Legal system of Ukraine: globalization transformations. Zaporozhye: KSK, 2014. 320 p. 
sis of common European and world legal values and standards.

Globalization as a defining tendency of modern age accelerates and deepens interaction, strengthens interdependence of legal systems, causes their gradual convergence, integration, formation of common legal and cultural environment, accompanied by recognition of common values, principles, norms, standards, clash of different legal traditions. Globalization intensifies the implementation and realization of international legal standards in law enforcement activities. Legal ideology is an important fundamental component of the processes of democratic transformation of social relations in general, formation and functioning of an effective legal system of society in the context of globalization, in particular. The development and evolution of statehood and civil society are not possible without strengthening their legal basis, without substantiated legal ideology.

In modern legal literature, legal ideology is characterized as a complex, contradictory, complex phenomenon, which includes a set of legal ideas, theories, concepts, paradigms, beliefs, ideas about the most optimal legal development of the national legal system from a nation-state. M. Nediukha, analyzing this problem, concludes that legal ideology is a set of legal ideas, views and norms that, in conceptual dimension, reflect evaluate and set the goals to the process of social change, contribute to strengthening the legitimate foundations of the functioning of the state and society, positioning the country and society in European and world space ${ }^{42}$. In modern legal literature, legal ideology is characterized as a complex, contradictory, complex phenomenon, which includes a set of legal ideas, theories, concepts, paradigms, beliefs, ideas about the most optimal legal development of the national legal system from a nation-state. M. Nediukha, analyzing this problem, concludes that legal ideology is a set of legal ideas, views and norms that, in conceptual dimension, reflect evaluate and set the goals to the process of social change, contribute to strengthening the legitimate foundations of the functioning of the state and society, positioning the country and society in European and world space ${ }^{43}$.

\footnotetext{
${ }^{42}$ NEDIUKHA, M. P. Legal ideology of Ukrainian society. Kyiv: Interregional Academy of Personnel Management, 2016. 481 p.

${ }^{43}$ NEDIUKHA, M. P.; PODOLYAKA, S. A. Theoretical and legal and state-building potential of legal (constitutional) ideology in a multicultural society. Multiculturalism as a socio-legal phenomenon: the challenges of the globalized world. Kyiv: LLC “Art-Technology”, 2015. 205 p.
}

Legal ideology affects various subsystems of the legal system, including the development of legal culture. Legal ideology is able to enrich it with those ideas, values, concepts and principles that change the legal culture, increase its level, and allow it to be disseminated to citizens of the state. In the context of the above-mentioned and in agreement with the opinion of A. Lutskyi, it may be said that legal ideology is the driving force of accelerating the influence of the state on society and is an element of the legal system, which acts as a form of unity of the state and society and at the same time - as a sphere of confrontation of the state and society for priority ideological tendencies ${ }^{44}$.

\subsection{Problems of national legal ideology under the conditions of transformation of the legal system of Ukraine}

While agreeing with the scientific works of M. Nediukha, it should be noted that the national legal ideology is determined by the peculiarities of the interaction of universal (planetary), continental (regional) and national aspects ${ }^{45}$. Adequate globalization of legal ideology is possible only if the specific nature of the national life of the Ukrainian people is taken into account, its proper identification in the unity of three components - social truth, social positioning and construction of Ukraine as a country, state and society. The origin of this view is the elemental composition of legal ideology, in particular: the conception and concept of law and legal phenomena in society; legal ideas, categories aimed at revealing the essence and laws of the development of legal life and the life of society in general; theories and teachings that characterize the legal system in its development and interaction with other social systems.

Considering the structural components of legal ideology, it is possible to distinguish the directions of its influence on the process of transformation of the legal system and the formation of civil society: 1) determining the prospects of development of the national system of law, goals of social development, as well as ways and legal means of their implementation; 2) esta-

${ }_{44}$ LUTSKYI, A. I. Modern philosophical-legal and theoretical-legal thought about legal ideology (experience of Ukraine and Post-Soviet countries). Bulletin of Zaporizhia National University: A Collection of Scientific Papers. Legal Sciences, n. 4, p. 24-30, 2013.

45 NEDIUKHA, M. P. Worldview-theoretical principles of legal ideology. Chamber, n. 21, v. 258, p. 27-30, 2009. 
blishment of legal mechanisms and legal regulators of the functioning of the state and society as a single space that functions and develops in accordance with the requirements, requests and needs of national interests; 3 ) providing a legal assessment of the socio-legal reality from the point of view of approaching the social goal, standards of quality and standards of living, social, legal order and justice; 4) promoting the functioning of society as an integral social organism, the highest value of which is a person, his/her rights and freedoms; 5) laying the theoretical and methodological bases for determining the meaningful and functional characteristics of legal policy, namely: conceptual substantiation of the development of national legislation; finding out tendencies of the process of changes of the Ukrainian society in the part of political and legal support of its functioning or, at least, tendencies of development of national legislation; legislative support of priority spheres of public relations; 6) formation of a safe social, political and legal space, based on the assertion and realization of human and citizen's rights and freedoms as starting, fundamental principles for finding adequate answers to the challenges, risks and dangers of the globalized world, etc.

Implementation of large-scale legal reforms, improvement of the system of public administration, development of civil society institutions is impossible without quality work of all bodies of the legislative, executive and judicial branches of power. But the current legal development of Ukraine is not characterized by ideological completeness, strategic and ideological clarity, and does not fully correspond to the mentality of society, its development prospects, which, in general, has a negative impact on the implementation of law-making (legislative process, the formation of the content of laws, determining their doctrinal or axiological direction), law enforcement (ensuring the rights and freedoms of a human and a citizen) activities. The lack of legal ideology is the consequence of ignoring certain established traditions of rule-making, law-making and legislative activities, makes attempts to uncritical transfer of law-making projects of Western European standards to national territories, and attempting to solve social problems of modernization development through administering, herein neglecting legal national interests of citizens. In addition, the obvious shortcomings of such processes are a number of gaps related to the low level of legal awareness of citizens, outdated archetypes of public administration, corruption, etc ${ }^{46}$. That is why the legal ideology, which is grounded in accordance with the provisions of classical, non-classical and post-classical intellectual traditions, becomes an important factor of the formation of civil society, legal socialization of the individual, affirms and develops domestic traditions of law-making, legislative and law-enforcement and, accordingly, counters unlawful attempts to regulate social relations.

The current national legal ideology of Ukraine, under the influence of globalization and internal social problems, is in a state of dynamic transformation and complication. Ukraine faced the issues of preserving the national sovereignty of the state under the conditions of globalization, its membership in international, supranational organizations, the orientation of the essential and meaningful transformations of the national legal system. It became clear that the problems of transformation of the legal system, including the legal ideology as its integral subsystem, are related to the evolution of the process of managing social and legal processes and qualitatively new, more optimal and adequate new modern realities requirements for the implementation of legal regulation of social relations.

That is, in the context of globalization, social and state development is accompanied by profound systemic changes that give rise to the interconnection and interdependence of almost all spheres of public and state life through their universalization and standardization. This is due to the fact that legal globalization is the process of creating unified legal principles and methods of legal regulation and the system of law enforcement in order to form a unified legal system and supranational mechanisms of legal regulation ${ }^{47}$.

An important direction in the development of national legal ideology is the introduction of generally accepted democratic procedures and the creation of favorable conditions for the development of civil society institutions. Noteworthy are the tools that developed foreign countries use for the powerful development of civil society. Thus, today various forms of public control have been developed: the Institute of concept and essence. Eurasian Legal Journal, n. 4, p. 91-93, 2017. 
Local Commissioners for Human Rights (UK, France, Canada, Australia, Italy, USA), citizens' appeals (USA and European Union countries), public consultations (Canada), public councils (Poland, France, Spain, Canada, Belgium) and others ${ }^{48}$.

The experience of effective implementation of the interaction of the state and the public in the conditions of democratization of all spheres of public life is demonstrated by the USA, where the forms of direct participation of the population in the decision of local questions acquire special development. In particular, such forms include volunteering, initiating forums to discuss strategic issues, supervisory boards of public activities, the use of information resources to establish partnerships between government and society. The introduction and implementation of such tools contribute to the awareness of each citizen of their own involvement in the implementation of a coordinated public policy ${ }^{49}$. Kolesnikova, as a result, the national-state legal self-consciousness of citizens is the basis for the formation of a worldview that corresponds to the mentality of society and, at the same time, creates a favorable environment for society to assimilate legal values ${ }^{50}$.

In the context of the analysis of effective means of development of legal ideology it is necessary to pay attention to the corporate continental- European model of activity of non-governmental organizations which is characteristic of Germany, Sweden, Belgium, France, and the Netherlands. In such a model, under the influence of strong traditions of decentralization, a favorable political environment and a developed social security system, there are powerful public organizations that have a long history of development and are united around ideological preferences. Non-governmental organizations in European countries are fully integrated into the structures of civil society, and their activities are professional ${ }^{51}$. Unlike foreign countries, in Ukraine

\footnotetext{
48 SKVIRSKY, I. O. Public control over public administration in foreign countries: general principles of organization and implementation. European Perspectives, n. 7, p. 11-17, 2013.

49 KHALETSKY, A. V. Foreign experience in promoting the development of civil society. Public Administration: Improvement and Development, n. 11, 2012. Available at: http://www.dy.nayka.com. ua/?op $=1 \& z=546$. Accessed on: 3 May 2021.

${ }^{50}$ KOLESNIKOVA, G. I. The social mechanism of manipulation of personality consciousness. Moscow: Direct Media, 2014. 272 p.

51 USACHENKO, L. M. Foreign experience of non-governmental organizations: functional models. Public Administration: Theory and Practice, n. 1, 2010. Available at: http://www.uk.x-pdf. ru/5mehanika/1204463-2-usachenko-doktor-nauk-derzhavnogo-
}

government institutions do not consider society as a reliable partner, and non-governmental organizations, in turn, lose influence in the formation of ideology and ignore their mediation purpose. According to V. Alekseev, instead of using foreign experience in material support of public administration structures to establish close relations between the subject and the object of public administration, public organizations in Ukraine have become ineffective institutions seeking only foreign grants ${ }^{52}$.

The process of formation of modern national legal ideology in the conditions of transformation of the legal system of Ukraine taking into account the best foreign practices cause the problem of preservation of national identity. Because globalization effect on the legal sphere, which, as a rule, consists in the qualitative transformation of existing legal and state phenomena, often leads to the loss of value and identity of the national legal system, which reflects the specifics of national legal consciousness, legal culture, legal ideology, dominant legal understanding, legal mentality, which is conditioned by the legal tradition and values in society ${ }^{53}$.

The influence of globalization on the development of the national legal system cannot be assessed unequivocally, since on the one hand there is borrowing the positive experience of other states, which contributes to the unification of legal standards, and on the other - the process of modernization of national legislation becomes a "legal expansion" stronger states in economic and political terms. Therefore, the issue of ways and methods of overcoming the negative effects of the impact of globalization on national identity is one of the most pressing at this stage of development of the Ukrainian state.

The condition for overcoming the problems of development of the legal system of Ukraine is to take into account the diversity of legal cultures, which provides a symbiosis of the universal and the original one in each culture, and the formation of a legal culture capable of creating a single fundamental basis for the develop-

upravlinnya-zarubizhniy-dosvid-neuryadovih-organizaciy-funkcionalni-modeli-stattya-p.php. Accessed on: 3 May 2021.

52 ALEKSEEV, V. M.; LIPOVSKAYA, N. A. The relationship between state and society. Dnipro: GRANI, 2019. 65 p.

${ }^{3}$ BOHDAN, S.; VITALII, K.; TARAS, H.; DMYTRO, Z.; SERHII, K. Historical and legal analysis of development of administrative responsibility for unauthorized occupation of a land plot. Journal of Legal, Ethical and Regulatory Issues, n. 6, v. 22, p. 1-7, 2019. 
ment of all elements of the national legal system. The process of legal infiltration can minimize the negative effects of globalization and preserve the identity of the national legal system, avoid and resolve conflicts of entry of international law into the system of national legislation. This process will allow to borrow partially the provisions of the international legal community and those rules of law that are not alien, and, accordingly, after successful borrowing of their functioning to achieve effective results ${ }^{54}$. Also, an effective way of optimizing the undesirable effects of the transformation of the national legal system in today's world trends is a performance of interaction on the basis of a pluralistic paradigm that recognizes the differences that exist between national legal cultures and legal ideologies, as well as historically determined legal traditions and value orientations of certain societies.

However, while preserving the identity of the national legal culture, we should not ignore the new legal traditions that emerge and develop in foreign countries. Ukraine's legal ideology is in the process of being filled with new content, which is connected with the transition from a totalitarian to a democratic society. It must be based on comprehension, awareness and unconditional recognition of the value concept of the rule of law. Based on the fact that justice is an element of legal ideology, and the formation of a single national idea should take place through a constructive dialogue and interaction between state and public, we can talk about the relevance of implementing methods of alternative dispute resolution and ensuring the functioning of mediation. As N. Bozhenko points out, in the second half of the twentieth century. There was a general rejection of state paternalism and the transition to a pluralistic approach $^{55}$. This approach provides an opportunity for participants in public relations to choose the optimal form of interaction. The introduction and modernization of existing methods of alternative dispute resolution is a prerequisite for the formation of civil society, due to a significant increase in the level of independen-

\footnotetext{
${ }_{54}$ TSYPKO, V.; ALIEKSIEIEVA, K. I.; VENGER, I. A.; TAVOLZHANSKYI, O. V.; GALUNETS, N. I.; KLYUCHNIK, A. V. Information Policy of the Enterprise as the Basis for the Reproduction of Human Potential in the Structure of Public Social Interaction. Journal of Advanced Research in Law and Economics, n. 6, v. 10, p. 1664-1672, 2019.

55 BOZHENKO, N. V. Administrative and legal support of mediation as a way of resolving administrative disputes. Zaporizhzhia: Zaporizhzhia National University, 2018. 18 p.
}

ce and self-responsibility of citizens who turn to such means. New social institutions of mediation, which embody the ideas of social dialogue and peaceful settlement of conflict situations in society as part of the legal ideology, will ensure the dynamic development of the national legal system.

In view of the above-mentioned, it is worth noting that the development and meaningful renewal of national legal ideology continues, and is accompanied by the clash of different views and beliefs. Legal globalization is accompanied by the spread of liberal legal ideology and, at the same time, the ideology of globalism, which is inherently eco-centric, is guided by the values of the free market, to which the legal, environmental, cultural and political values, etc. are submitted.

\section{Conclusions}

Different aspect examination of the researched category in the context of the development of the rule of law state and the formation of civil society, as well as the identification of synergistic patterns of its interaction with other legal phenomena of the legal system allows drawing conclusions:

1. Legal ideology is a holistic, self-organizing, artificially created on the basis of philosophical or religious doctrines mechanism of influence of the system of ideas on social, group and individual consciousness in order to legitimize (delegitimize) the positive law, legal practice, legal system by transferring legal ideas into normative settings of consciousness and forming appropriate models of behavior.

2. The study of legal ideology is carried out in the following directions: firstly, as a form of legal activities of different subjects of law, the regulatory attitudes of consciousness and the formation of appropriate patterns of behavior; secondly, as a set of measures, tasks, programs, guidelines for achieving certain goals (first of all, establishment of the rule of law state and protecting the rights and freedoms of an individual and a citizen); thirdly, as a social and legal phenomenon immanently connected with the legal culture and legal consciousness; fourthly, as a legal category.

3. Legal ideology covers all processes of law-making and the implementation of law, contains ideas, concepts, 
assessment of prospects for the development of law, goals and objectives of adoption of certain regulations, basic principles and specific content of legal regulation.

4. Legal ideology is closely related to the existing concepts of legal consciousness, legal theories, and doctrines. It can find expression in the existing legal acts, as it significantly affects the will and consciousness of the legislator, who embodies separate legal ideological concepts in the laws.

5. Legal ideology, as a component of justice, has a number of characteristics:

- is the higher level of reflection of socio-economic relations enshrined in normative legal acts, which not only expresses legal validity but also actively influences it;

- always manifests itself through conscious volitional activity, as a result of which it can act on people in various ways of influence on legal behavior: information, adaptation, value, motivational, regulatory-binding, etc.;

- cannot exist without its specific holder - human, social groups, collectives and connected with the process of socialization of the individual, as life experience and social practice determine the formation of his legal preferences and motives;

- directs the activities of public authorities to achieve a set of determinants: national interests, social development, democracy, social mobility and fair remuneration.

6. Formation of legal ideology is impossible without taking into account the historical past, moral and spiritual origins, religious orientation, self-awareness and values, national peculiarities of social and legal reality, legal awareness and legal culture of each individual in society.

7. Pluralism of ideologies guaranteed by Art. 15 of the Constitution of Ukraine, stipulates the urgent need for the formation of a grounded national legal ideology as a conceptual basis of legal policy, which in meaningful and functional aspects should obey the principle of the rule of law; guarantee the rights and freedoms of an individual and a citizen; promote the formation of a coherent national legal system and the functioning of the rule of law and civil society; protect national interests; create adequate and effective political and legal means of securing against the challenges, risks and dangers of globalization; ensure the effectiveness of legislation, as- sert the international authority of Ukraine and position it as a civilized European state in the global legal space.

8. Avoiding the declarative nature of Ukraine's national legal ideology is possible by:

- ensuring the normative nature of its action in society and the state;

- establishing it as a socio-legal phenomenon, reflecting the worldview, moral, ethical and legal precepts of the individual and society as a whole, the mentality of the people, customs, traditions, etc.;

- subordination to the tasks of development of Ukraine in view of the interaction of three elements: country, state and society;

- formation of the national idea and development of legal culture;

- establishing a dialogue between the state and civil society, promoting the development and support of the information society;

- increasing the role of the public in the process of determining the strategic directions of development of the national legal system and promoting the development of the network of public organizations;

- introduction of generally accepted democratic procedures (forms of feedback, public discussion, denial of the content of bills, proposals and additions to them), development of e-government, introduction of alternative methods of resolving disputes between government and society, which together will not only form a legal ideology and will increase the level of legal culture, but also reflect the legal values of society.

\section{References}

ALEKSEEV, V. M.; LIPOVSKAYA, N. A. The relationship between state and society. Dnipro: GRANI, 2019.

ALIMBEKOVA, M. A.; IBRAYEVA, A. S.; ICHSHANOVA, G. T.; USEINOVA, K. R.; IBRAYEV, N. S. Legal culture of public servants: The comparative legal analysis of the formation practices of various countries. Journal of Advanced Research in Law and Economics, n. 7, v. 10, p. 1956-1967, 2019. 
ASTAKHOVA, V. I.; BOGIROV, V. S.; GORODYANENKO, V. H. et al. Sociological encyclopedia. Kyiv: Akademvydav, 2008.

BOHDAN, S.; VITALII, K.; TARAS, H.; DMYTRO, Z.; SERHII, K. Historical and legal analysis of development of administrative responsibility for unauthorized occupation of a land plot. Journal of Legal, Ethical and Regulatory Issues, n. 6, v. 22, p. 1-7, 2019.

BOZHENKO, N. V. Administrative and legal support of mediation as a way of resolving administrative disputes. Zaporizhzhia: Zaporizhzhia National University, 2018.

DZYUNDZIUK, B. V. Foreign experience of interaction of authorities with citizens in the conditions of development of information society. Bulletin of the National University of Civil Defense of Ukraine. Series: Public Administration, n. 2, p. 94-101, 2016.

EUROPEAN COMMISSION. WhitePaperongrowth, competitiveness and employment: the challenge and ways forward into 21 st century. Available at: https://op.europa.eu/ en/publication-detail/-/publication/4e6ecfb6-471e4108-9c7d-90cb1c3096af/language-en. Accessed on: 3 May 2021.

GERASINA， L. M.; POGRIBNA， V. L.; POLISHCHUK, I. O. Political science encyclopedic dictionary. Kharkiv: Law, 2015.

HART, H. L. A. Are there any natural rights? Philosophical Review, n. 64, v. 2, p. 175-191, 1955. Available at: https://www.jstor.org/stable/pdf/2182586. pdf?seq=1. Accessed on: 3 May 2021.

KHALETSKY, A. V. Foreign experience in promoting the development of civil society. Public Administration: Improvement and Development, n. 11, 2012. Available at: http:/ /www.dy.nayka.com.ua/?op $=1 \& z=546$. Accessed on: 3 May 2021.

KOLESNIKOVA, G. I. The social mechanism of manipulation of personality consciousness. Moscow: Direct Media, 2014.

KUCHERKOV, I. A.; VORONINA, T. V. Legal globalization: concept and essence. Eurasian Legal Journal, n. 4, p. 91-93, 2017.

KALIUZHNYJ, R. A.; SHAPENKO L. A. The conceptual content of subjective law in terms of legal integration. Scientific works of the National Aviation University. Series: Legal Bulletin "Air and Space Law", n. 4, v. 53, p. 54-61, 2019.
LANE, D. Civil society in the old and new member states. European Societies, n. 12, v. 3, p. 293-315, 2010.

LEES, E.; SHEPHERD, E. Morphological analysis of legal ideology: locating interpretive divergence. Journal of Property, Planning and Environmental Law, n. 10, v. 1, 2018. Available at: http://centaur.reading.ac.uk/75250/. Accessed on: 3 May 2021.

LUTSKYI Morality and law in the system of social ideas and their place and role in the activities of the National Police of Ukraine: monograph. Lviv: Lviv Department of Internal Affairs, 2017.

MANNHEIM, K. Ideologie und Utopie. Bonn: Friedrich Cohen, 1929, 250 p. Available at: https://books.google. com.ua/books?id=NxethJLLfGoC\&pg $=$ PR53\&lpg $=$ P $\mathrm{R} 53 \& \mathrm{dq}=$ Mannheim,$+\mathrm{K} .+$ Ideologie + und + Utopie. $+\mathrm{B}$ onn,+1929. Accessed on: 3 May 2021.

MARKOVYCH, K. Legal ideology as a basis of forming civil society. Law, n. 885(12), v. 1, p. 418-423, 2016.

MARX, K.; ENGELST, F. Selected works. Moscow: Politizdat, 1985. v. 2.

MATVIEIEVA, L.; BALTAJI, P.; KONOPELSKY, V. Role of modern legal elite in formation of legal culture of Ukrainian society. Asia Life Sciences, n. 2, p. 385-403, 2019.

MATVIENKIV, S. M. Transformation of political consciousness in the conditions of formation of democracy in Ukraine: monograph. Ivano-Frankivsk: NAIR, 2018.

NEDIUKHA, M. P. Legal ideology of Ukrainian society. Kyiv: Interregional Academy of Personnel Management, 2016.

NEDIUKHA, M. P. Legal ideology of Ukrainian society: monograph. Kyiv: MP Lesya, 2012.

NEDIUKHA, M. P. Worldview-theoretical principles of legal ideology. Chamber, n. 21, v. 258, p. 27-30, 2009.

NEDIUKHA, M. P.; PODOLYAKA, S. A. Theoretical and legal and state-building potential of legal (constitutional) ideology in a multicultural society. Multiculturalism as a socio-legal phenomenon: the challenges of the globalized world. Kyiv: LLC “Art-Technology”, 2015.

NEUHODNIKOV, A. Civil society control of public administration activities: alignment to international standards. Lex Portus, n. 6, v. 20, p. 66-80, 2019. 
ONISHCHENKO, N. M; PARKHOMENKO, N. M. Social dimension of the legal system: realities and prospects: monograph. Kyiv: Legal Thought, 2011.

POPELOVA, I. Ethics. On historical and modern issues of moral theory. Moscow: Progress, 1965.

PYS $\square$ MENNYY, I. Public attractors as a basis for forming the synergetic potential of public administration. 2010. Available at: http://www.dridu.dp.ua/vidavnictvo/2010/201 0_04(7)/10pivppu.pdf. Accessed on: 3 May 2021.

SHEVCHENKO A. E.; KHOLODNIUK S. Z. Sociolegal value of man in modern law: monograph. Vinnytsia: LLC "TVORY", 2019.

SIROTA, N. M. Ideologies and ideological currents: classical heritage and modernity. St. Petersburg: IVESEP, 2009.

SKVIRSKY, I. O. Public control over public administration in foreign countries: general principles of organization and implementation. European Perspectives, n. 7, p. 11-17, 2013.

SOPILKO, I. M. Methodological bases of scientific comprehension of the concept of information society. Legal Bulletin. Air and Space Law, n. 1, p. 80-84, 2014.

THÜRER, D. Soft law. Oxford Public International Law. 2009. Available at: https://opil.ouplaw. com/view/10.1093/law:epil/9780199231690/law9780199231690-e1469?prd=EPIL. Accessed on: 3 May 2021.

TOLSTENKO, V. L. Legal ideology in the structure of legal consciousness: theoretical and methodological bases of analysis. State and Law: Collection of Scientific Works. Legal and Political Sciences, n. 41, p. 10-18, 2008.

TSYPKO, V.; ALIEKSIEIEVA, K. I.; VENGER, I. A.; TAVOLZHANSKYI, O. V.; GALUNETS, N. I.; KLYUCHNIK, A. V. Information Policy of the Enterprise as the Basis for the Reproduction of Human Potential in the Structure of Public Social Interaction. Journal of Advanced Research in Law and Economics, n. 6, v. 10, p. 1664-1672, 2019.

UDOVYKA, L. G. Legal system of Ukraine: globalization transformations. Zaporozhye: KSK, 2014.

UDOVYKA, L. G. Transformation of the legal system in the context of globalization: anthropological dimension: monograph. Kharkiv: Pravo, 2011.

USACHENKO, L. M. Foreign experience of non-governmental organizations: functional models. Public Ad- ministration: Theory and Practice, n. 1, 2010. Available at: http://www.uk.x-pdf.ru/5mehanika/1204463-2-usachenko-doktor-nauk-derzhavnogo-upravlinnya-zarubizhniy-dosvid-neuryadovih-organizaciy-funkcionalnimodeli-stattya-p.php. Accessed on: 3 May 2021.

VAPNIARCHUK, V. V.; PUCHKOVSKA, I. I.; TAVOLZHANSKYI, O. V.; TASHIAN, R. I. Protection of ownership right in the court: the essence and particularities. Asia Life Science, n. 2, v. 21, p. 1-19, 2019.

YEVKHUTICH, I. M. Morality and law in the system of social ideas and their place and role in the activities of the National Police of Ukraine: monograph. Lviv: Lviv Department of Internal Affairs, 2017. 
Para publicar na Revista de Direito Internacional, acesse o endereço eletrônico www.rdi.uniceub.br ou www.brazilianjournal.org.

Observe as normas de publicação, para facilitar e agilizar o trabalho de edição. 